\title{
Chromium (VI) - induced stress response in the plant Plantago ovata Forsk in vitro
}

\author{
Debangana Kundu, Sankalan Dey and Sarmistha Sen Raychaudhuri (i)
}

\begin{abstract}
Background: Plants experience severe physiological stress from heavy metal pollution caused by improper discarding of the industrial wastes. Hexavalent chromium $[\mathrm{Cr}(\mathrm{VI})]$ is one of the major heavy metal pollutants in India and is present particularly in some regions where Plantago ovata grows to a great extent. This study was aimed at finding the effects of $\mathrm{Cr}(\mathrm{VI})$ on $P$. ovata and manoeuvres of the plant to combat such heavy metal exposure in vitro.
\end{abstract}

Methods: Potassium dichromate was used as a source of $\mathrm{Cr}(\mathrm{VI})$ to induce the heavy metal stress. Range of $\mathrm{Cr}(\mathrm{VI})$ sublethal doses [0 mM (control), $0.1 \mathrm{mM}, 0.3 \mathrm{mM}, 0.5 \mathrm{mM}, 1 \mathrm{mM}, 1.5 \mathrm{mM}$ and1.8 mM] was used to observe its effect on the plant. The seeds of the plant were grown on sucrose-agar media with different concentrations of potassium dichromate, and ten-day old seedlings were then harvested and examined.

Results: The germination rate reduced below $50 \%$ at $1.9 \mathrm{mM} \mathrm{Cr}(\mathrm{VI})$ concentration and thus, $0 \mathrm{mM}-1.8 \mathrm{mM}$ concentration ranges were found to be suitable for sublethal dose. Morphological changes namely, reduction of the shoot-root length and multiple root development were caused by $\mathrm{Cr}(\mathrm{VI})$ in a dose-dependent manner. The plant showed elevated responses against $\mathrm{Cr}(\mathrm{VI})$, up to $1.5 \mathrm{mM}$ (10 days treated) in terms of increasing accumulation of secondary metabolites like polyphenols, chlorophyll content (chlorophyll a, b and total chlorophyll), carotenoids and total antioxidant activity. DPPH radical scavenging activity along with malondialdehyde (MDA) content was not significantly elevated with the increase in $\mathrm{Cr}(\mathrm{VI})$ concentration indicating that the lipid peroxidation rate within the tissue was low. Phenylalanine ammonia lyase (PAL) and polyphenol oxidase (PPO) gene expressions were upregulated by $1 \mathrm{mM} \mathrm{Cr}(\mathrm{VI})$ concentration, which decreased at higher concentrations. The atomic absorption spectroscopy analysis also showed significant accumulation of $\mathrm{Cr}(\mathrm{VI})$ in the shoot and root with an increase in the potassium dichromate concentration.

Conclusion: $\mathrm{Cr}(\mathrm{VI})$ reduced the shoot-root length and seed germination in a dose-dependent manner. The plant system tried to combat the $\mathrm{Cr}(\mathrm{VI})$ stress by upregulating the stress response genes in the phenylpropanoid pathway along with an increase in polyphenol and antioxidant contents, which were evident from the lowering of lipid peroxidation rate and increase in PAL and PPO gene expressions.

Keywords: Plantago ovata, Hexavalent chromium (Cr VI), Stress, Polyphenols, Polyphenol oxidase (PPO), Phenylalanine ammonia lyase (PAL), Tolerance

\footnotetext{
*Correspondence: sarmistharc@gmail.com; sarmistha_rc@rediffmail.com Department of Biophysics, Molecular Biology, and Bioinformatics, University of Calcutta, 92, APC Road, Kolkata 700009, India
}

(c) The Author(s). 2018 Open Access This article is distributed under the terms of the Creative Commons Attribution 4.0 International License (http://creativecommons.org/licenses/by/4.0/), which permits unrestricted use, distribution, and reproduction in any medium, provided you give appropriate credit to the original author(s) and the source, provide a link to the Creative Commons license, and indicate if changes were made. The Creative Commons Public Domain Dedication waiver (http://creativecommons.org/publicdomain/zero/1.0/) applies to the data made available in this article, unless otherwise stated. 


\section{Background}

Heavy metals are the natural constituents of soil, but can cause pollution due to unregulated disposal which increases their concentration in soil and induces stress to both plants and animals. Plants growing on such contaminated soil were found to show several physiological changes to combat the heavy metal stress. Chromite is a natural form of chromium $(\mathrm{Cr})$ and is found in ultramafic and serpentine rocks in various forms such as, crocoite $\left(\mathrm{PbCrO}_{4}\right)$, tarapacite $\left(\mathrm{K}_{2} \mathrm{CrO}_{4}\right)$, etc. [1]. Chromium is also one of the heavy metal pollutants, produced from various sources like steel industries, metal smelters, leather tanning, emissions from industries and also, from pesticide and fertilizer use [2-5]. Reported documents on hexavalent chromium [Cr (VI)] pollution estimated at various parts of the world, revealed its presence in the different industrial regions of India. $\mathrm{Cr}$ pollutants are found to be present in the industrial zone of Vadodara [6]. The soil of Surat, Gujarat also contains various heavy metal pollutants of which $\mathrm{Cr}$ was reported to be $305.2 \mathrm{mg} / \mathrm{kg}$ of soil which is higher than the permissible limit prescribed by the WHO guidelines [7].

$\mathrm{Cr}$ is found in two ionic forms chromic [Cr (III)] and chromate [Cr (VI)] in the soil. $\mathrm{Cr}$ (VI) is more stable and soluble than Cr (III) and percolates deeply into the ground, which leads to groundwater pollution [8]. Like any other heavy metals, $\mathrm{Cr}$ is toxic to plants at higher concentrations and is not essential for plant growth metabolism [9]. Cr (VI) has been found to be more stable, and thus more toxic to plants [4]. Plants exposed to $\mathrm{Cr}$ stress, develop metabolic impairment and results in alteration of many physiological processes leading to the reduction of the germination rate, growth, chlorosis, stunting, and finally plant death [4,9]. Some plant species such as Nymphaea alba L. [5], Oryza sativa L. [10], Clusterbean [11] are susceptible to Cr stress; whereas, some plants such as Ocimum tenuiflorum L. [4], Jatropha curcas L. [2] Bacopa monnieri L. [12], are quite tolerant. Plants have various defence mechanisms to endure such heavy metal stress. Genes involved in the secondary metabolic pathway like phenylalanine ammonia lyase (PAL) and polyphenol oxidase (PPO) $[2,13]$ initiate stress responses and help plants to adapt against abiotic stresses. Plant secondary metabolite accumulation is regarded as a responsive behaviour of plants to tolerate stress [14].

In this study, Plantago ovata Forsk. was chosen as a test system. It is mainly grown in India, Iraq, Canary Island and Spain [15]. In India, it is cultivated in Gujarat, and as discussed earlier, $\mathrm{Cr}$ pollution is quite evident in Gujarat [7]. Seed husk of P. ovata is widely used as a laxative to cure the intestinal disorder. It also has various other medicinal properties [16, 17]. Many studies have been conducted related to the effect of heavy metal exposure in the genus Plantago. Serrano et al. [18] have corroborated the heavy metal hyperaccumulation trait among Plantago genus. Several species of Plantago show hyperaccumulation of various metal pollutants like aluminium $(\mathrm{Al})$, zinc $(\mathrm{Zn})$, copper $(\mathrm{Cu})$, lead $(\mathrm{Pb})[18]$. Plantago arenaria is tolerant to $\mathrm{Cu}$, cadmium $(\mathrm{Cd})$, nickel (Ni) and Zn [19]. Khan et al. [20] considered $P$. ovata as a hyperaccumulator of $\mathrm{Pb}$, as it can grow in soil with concentration up to $4 \mathrm{mM}$. Since effects of $\mathrm{Cr}$ (VI) on $P$. ovata have not been studied yet; the present study was conducted to understand the underlying mechanisms of $\mathrm{Cr}$ (VI) toxicity towards $P$. ovata by observing the morphological and physiological responses towards the stress.

\section{Method}

\section{Tissue culture media preparation}

Sucrose-agar media were prepared with $3 \%(w / v)$ sucrose and $0.9 \%(\mathrm{w} / \mathrm{v})$ agar. Ten seeds were transferred on to $10 \mathrm{ml}$ of the prepared media contained in each $50 \mathrm{ml}$ culture tubes (Borosil). Sublethal concentrations (0.1 mM, 0.3 mM, 0.5 mM, $1 \mathrm{mM}, 1.5 \mathrm{mM}$ and $1.8 \mathrm{mM}$ ) of potassium dichromate (SRL, India) were also added in the media. Control media was kept devoid of potassium dichromate. The culture media were heat-sterilized using autoclave.

\section{Seed sterilization and transfer}

Plantago ovata seeds were imbibed overnight and then surface-sterilized for $20 \mathrm{~min}$ with $20 \%(w / v)$ sodium hypochlorite $(\mathrm{NaOCl})$. Seeds were washed with autoclaved double-distilled water for five times (each of 5 min duration) to wash off the excess bleach. Following inoculation of the seeds in the culture media, the culture tubes were kept in a controlled environment $\left(22{ }^{\circ} \mathrm{C}-25{ }^{\circ} \mathrm{C}\right.$ temperature, humidity of about $55 \%-60 \%$ ) under an artificial light intensity of $1500 \mathrm{~lx}$, kept on cycle for $16 \mathrm{~h}$ light and $8 \mathrm{~h}$ dark period every $24 \mathrm{~h}$. Seeds were allowed to grow for 10 days following the above growth conditions and tissue culture technique from the reported literature of Das (Pal) and Sen Raychaudhuri [21].

\section{Determination of root and shoot length}

Ten days-old seedlings were uprooted from sucrose-agar media keeping the root intact. The root and shoot length were measured using graph paper (where, $1 \mathrm{~cm}=1$ unit). The observations were repeated three times and the mean values were represented in S.I. unit.

\section{Seed germination studies}

Plantago ovata seeds were surface-sterilized with $20 \%$ $(w / v)$ sodium hypochlorite for $20 \mathrm{~min}$ and then rinsed thoroughly with distilled water. The seeds were then placed for germination on filter paper-lined Petri dishes (15 cm diameter) at $25{ }^{\circ} \mathrm{C}$ under artificial light intensity 
of $1500 \mathrm{~lx}$, kept under cycle for $16 \mathrm{~h}$ light and $8 \mathrm{~h}$ dark period (in $24 \mathrm{~h}$ ) for two days. Each Petri dish had $10 \mathrm{ml}$ of an aqueous solution of potassium dichromate, containing the specified sublethal concentrations. The data was recorded for three replicates of each treatment.

\section{Plant biomass calculation}

Seeds were thoroughly surface-sterilized, followed by germination in sucrose-agar media (with 3\% sucrose and $0.9 \%$ agar). After ten days of growth, four seedlings for each dose of potassium dichromate were gently uprooted and fresh weight (FW) was recorded. The seedlings were then oven-dried overnight at $70{ }^{\circ} \mathrm{C}$ and dry weight (DW) was recorded. The experiment was repeated three times.

\section{Preparation of plant tissue extracts}

Shoots of $P$. ovata were weighed in a high precision balance (Wensar PGB 100) for $100 \mathrm{mg}$ of fresh tissue, then crushed and homogenized with the pestle in mortar using $1 \mathrm{ml} 50 \%$ HPLC grade ethanol (Merck, Germany). The homogenized mixture was then subjected to sonication (VC 300, Vibra Cell, Sonic materials) for $20 \mathrm{~min}$ followed by centrifugation at $10,000 \times \mathrm{g}$ for $5 \mathrm{~min}$. The supernatant was collected for further biochemical analysis.

\section{Determination of total polyphenol content}

Folin-Ciocalteu reagent was used to determine the total polyphenol content spectrophotometrically, as described by Singleton et al. [22] with minor modification. Fifty $\mu$ lof plant extract was mixed with $250 \mu \mathrm{l}$ of Folin-Ciocalteu reagent and $750 \mu \mathrm{l}$ of $10 \%$ sodium carbonate $\left(\mathrm{Na}_{2} \mathrm{CO}_{3}\right)$, and then the mixture was shaken well and kept in the dark for $30 \mathrm{~min}$. Absorbance was measured at $760 \mathrm{~nm}$ using JASCO V-630 spectrophotometer. The concentration of polyphenol content was determined from the gallic acid (Sigma-Aldrich, USA) calibration curve and expressed as milligram (mg) gallic acid equivalent (GAE)/ gram (g) fresh weight.

\section{Estimation of total antioxidant activity}

The phosphomolybdenum method of Prieto et al. [23] was used to estimate total antioxidant activity of the samples. Phosphomolybdenum buffer was prepared by mixing 0.6 M sulphuric acid (Merck, Germany), $28 \mathrm{mM}$ sodium phosphate (Merck, Mumbai) and $4 \mathrm{mM}$ ammonium molybdate (Himedia, India) using autoclaved distilled water. Plant extract of $0.3 \mathrm{ml}$ was mixed with $3 \mathrm{ml}$ of the prepared buffer and then incubated at $95{ }^{\circ} \mathrm{C}$ for $90 \mathrm{~min}$. The assay works on the principle that molybdenum (VI) is reduced to molybdenum (V) by the plant extract and forms a green phosphomolybdate complex [24]. Absorbance was measured at wavelength $\left(\lambda_{\max }\right)$ of $695 \mathrm{~nm}$. Total antioxidant activity was estimated as milligram ascorbic acid equivalents (AAE) per gram of the fresh weight of $P$. ovata tissue using the ascorbic acid calibration curve.

\section{Determination of chlorophyll and carotenoid content}

The method of Sestak [25] and Lichtenthaler [26] was followed with minor modifications for total chlorophyll and carotenoids determination. Shoot tissue $(100 \mathrm{mg})$ from chromium (VI)-treated seedlings was crushed and homogenized with a pestle using ice-cold acetone in a mortar. The total volume was adjusted to $5 \mathrm{ml}$ with ice-cold acetone (SRL, India). The mixture was then centrifuged using a cold centrifuge machine $\left(4^{\circ} \mathrm{C}\right)$ for $10 \mathrm{~min}$ at $7728 \times \mathrm{g}$. The supernatant was collected and absorbance was measured according to the following equations:

$$
\begin{aligned}
& \text { Chlorophyll }(a)=11.24\left(A_{662}\right)-2.04\left(A_{645}\right) \\
& \begin{array}{r}
\text { Chlorophyll }(b)=20.13\left(A_{645}\right)-4.19\left(A_{662}\right) \\
\text { Total chlorophyll }=7.15\left(A_{663}\right)+18.71\left(A_{646}\right) \\
\text { Carotenoids }=\left[1000 A_{470}-1.90 \text { Chlorophyll }(a)\right. \\
-63.14 \text { Chlorophyll }(b)] / 214
\end{array}
\end{aligned}
$$

\section{Determination of DPPH radical scavenging activity}

The method of Brand-Williams et al. [27] of DPPH (1, 1-diphenyl-2-picrylhydrazyl) radical scavenging assay was followed with minor modifications. The assay works on the principle of reducing red-coloured stable free radical DPPH to DPPH-H, which turns to yellow upon reduction. The antioxidants present in the plant extract have the ability to scavenge the free radicals causing change in coloration and reduction of DPPH to DPPH-H [24]. DPPH working solution $(10 \mathrm{ml}$ of stock solution dissolved in $45 \mathrm{ml}$ methanol) was prepared from the DPPH stock solution (prepared using $24 \mathrm{mg}$ DPPH dissolved in $100 \mathrm{ml}$ methanol and stored at $-20{ }^{\circ} \mathrm{C}$ ). Plant extract of $150 \mu \mathrm{l}$ was mixed with $2.85 \mathrm{ml} \mathrm{DPPH}$ and incubated in the dark for an hour at room temperature. Absorbance was measured at $517 \mathrm{~nm}$ using a UV-VIS spectrophotometer. The ability of the plant extract to quench the free radicals was calculated by the following formulae:

$$
\begin{aligned}
& \text { DPPH radical scavenging activity }(\%) \\
& =\left[\left(A_{\text {control }}-A_{\text {sample }}\right) / A_{\text {control }}\right] \times 100
\end{aligned}
$$

where $A_{\text {control }}$ is the absorbance of the DPPH reagent without any sample extract and $\mathrm{A}_{\text {sample }}$ is the absorbance of the DPPH reagent along with each of the plant extract.

\section{Estimation of lipid peroxidation}

An increase in the production of reactive oxygen species (ROS) due to heavy metal stress, results in its reaction with the hydrogen of the methylene groups present in 
the polyunsaturated fatty acid of the cell membrane, thus, causing lipid peroxidation. This phenomenon causes damage to the membrane structure and function leading to the formation of aldehyde by-product such as malondialdehyde (MDA), the thiobarbituric reactive substance (TBARS) and 4-hydroxy-2-nonenal (HNE) [28].

The MDA content was measured to determine the lipid peroxidation state due to the $\mathrm{Cr}(\mathrm{VI})$ stress on $P$. ovata seedlings. Heath and Packer's method [29] was followed with some minor modifications. Plant tissue ( $P$. ovata shoot tissue weighing $100 \mathrm{mg}$ ) from each sample group was crushed in $1 \mathrm{ml}$ of $0.1 \%$ trichloroacetic acid (TCA) (SRL, India) followed by centrifugation of $1 \mathrm{ml}$ homogenized tissue for $14 \mathrm{~min}$ at $300 \times \mathrm{g}$. One $\mathrm{ml}$ of the supernatant from each sample was mixed with trichloroacetic acid-thiobarbituric acid (TCA-TBA), 0.5\% (w/v) TBA (SRL, India) mixed with $20 \%(\mathrm{w} / \mathrm{v})$ TCA, to form TCA-TBA solution. The mixture in the test tubes was allowed to heat at $95{ }^{\circ} \mathrm{C}$ in a water bath for $30 \mathrm{~min}$ and then cooled immediately on ice. Absorbance was measured at $532 \mathrm{~nm}$ against the TCA-TBA blank and non-specific absorbance was taken at $600 \mathrm{~nm}$. Lipid peroxidation was expressed as MDA equivalents as micromoles/ litre per gram fresh weight of the plant tissue. MDA extinction coefficient was taken as $155 \mathrm{mmol} \mathrm{L}^{-1} \mathrm{~cm}^{-1}$ [24].

\section{Phenylalanine ammonia lyase (PAL) activity assay}

Enzyme extract was subjected to PAL activity assay using the spectrophotometric method described by Kovácik et al. [30]. Plantago ovata seedlings (0.3 g) were homogenised in $2 \mathrm{ml} 0.1 \mathrm{M}$ sodium borate buffer ( $\mathrm{pH}$ 8.8) using a mortar-pestle. Homogenates were centrifuged $(15000 \times \mathrm{g})$ at $4{ }^{\circ} \mathrm{C}$ for $15 \mathrm{~min}$ and the collected supernatant was used as the enzyme extract. Sodium borate buffer $(500 \mu \mathrm{l})$ and enzyme extract $(350 \mu \mathrm{l})$ were pre-incubated at $40{ }^{\circ} \mathrm{C}$ for $5 \mathrm{~min}$. The reaction was then initiated by adding $300 \mu \mathrm{l}$ of $50 \mathrm{mM}$ l-phenylalanine. The reaction mixture was incubated at $40{ }^{\circ} \mathrm{C}$ for $60 \mathrm{~min}$, and then $50 \mu \mathrm{l} 5 \mathrm{~N} \mathrm{HCl}$ was added to stop the reaction. Absorbance was measured at $275 \mathrm{~nm}$, using the UV-Vis spectrophotometer (UV-1800, Shimadzu) to determine the amount of cinnamic acid formed. The enzyme activity was expressed as $\mu$ mol trans-cinnamic acid per min per gram FW of shoot tissue. Each sample was assayed in triplicate.

\section{Polyphenol oxidase (PPO) activity assay}

Enzyme activity was subjected to PPO assay and its activity was determined using a spectrophotometric method described by Arnnok et al. with minor modifications [31]. Plantago ovata seedlings (0.2 g) were ground thoroughly using a mortar-pestle in $0.1 \mathrm{M}$ phosphate buffer ( $\mathrm{pH}$ 7.0) containing polyvinylpyrrolidone. Homogenates were centrifuged at $1000 \times \mathrm{g}$ for
$20 \mathrm{~min}$. The supernatant was collected and then filtered through Whatman No. 42 filter paper. The filtrate was used as enzyme extract. Fifty $\mu \mathrm{l}$ of enzyme extract, $1.95 \mathrm{ml}$ of $0.1 \mathrm{M}$ phosphate buffer ( $\mathrm{pH} 7.0$ ) and $1 \mathrm{ml}$ of $0.1 \mathrm{M}$ catechol were taken into a test tube and mixed. Absorbance was measured at $410 \mathrm{~nm}$ continuously for $5 \mathrm{~min}$ using the UV-Vis spectrophotometer (V-630, Jasco). Each sample was assayed in triplicate. The enzyme activity was expressed as an increase in absorbance units (AU) per min per gram FW of shoot tissue.

\section{Primer designing for sequencing of polyphenol oxidase (PPO) gene}

Amino acid sequences of polyphenol oxidase gene of the related family of $P$. ovata, were obtained from the NCBI database and aligned. Clustal W2 software was used to find the conserved domain among the sequences. Primer3plus and Sigma DNA calculator were used to evaluate the parameters of the designed primer (Additional file 1: Table S1).

\section{Genomic DNA extraction and polymerase chain reaction (PCR)}

Extraction of DNA was done according to Edward et al. [32] with minor modifications. The primer designed above was used to amplify our desired gene (i.e., PPO). Specific PCR condition was maintained as shown in Additional file 1: Table S2. After amplification, the PCR product was subjected to agarose gel electrophoresis $(1.5 \%$ agar). Bio-Rad Molecular Imager (Gel Doc XR, Milan, Italy) was used to capture the gel image. The PCR product was sequenced and submitted to GenBank (Additional file 1: Table S2).

\section{Primer designing for expression analysis}

Specific primers for expression analysis were designed with the help of Primer3plus software from the above reported sequence of PPO gene (GenBank accession no: KM192264.1) in our lab (Additional file 1: Table S3). Primers used for $P A L$ gene expression and the endogenous control $\beta$-Actin [24] are also given in Additional file 1: Table S3.

RNA extraction and reverse transcription PCR (RT-PCR) for expression analysis

The Pure link RNA mini kit (Ambion, Thermo Fisher Scientific) was used to extract RNA from $P$. ovata leaves following the instruction manual. Spectrophotometric analysis was done to check the RNA purity and integrity. Specific primers for each gene were used to run the RT-PCR to examine the gene expression using the One-step RT-PCR kit (Qiagen). Reaction conditions were maintained as given in Additional file 1: Table S4. 

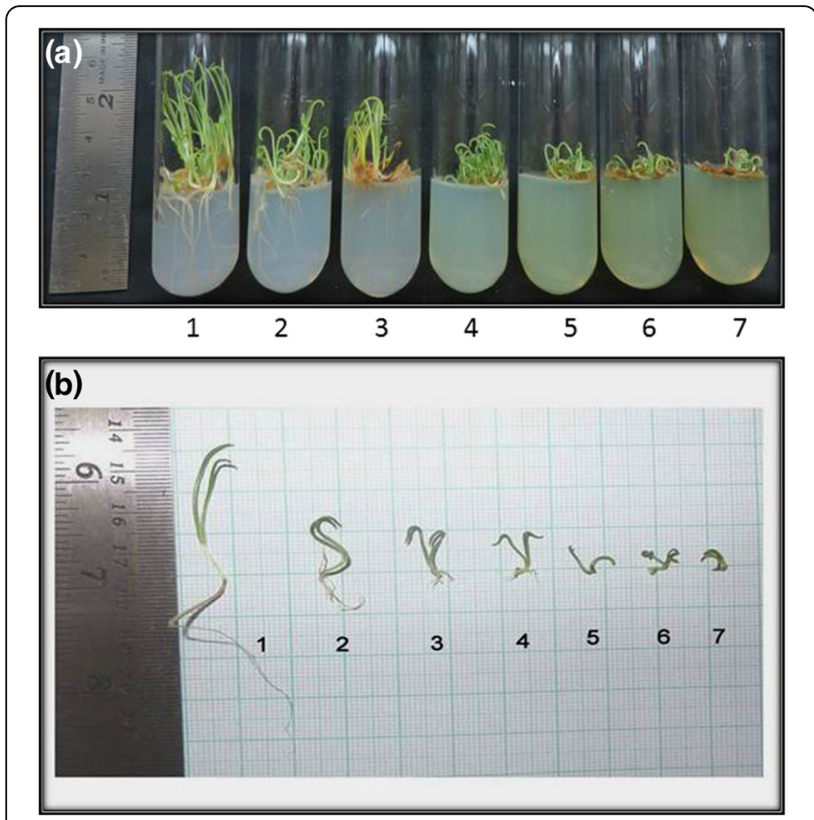

Fig. 1 Picture of 10 day-old $P$. ovata seedlings with different doses of $\mathrm{Cr}(\mathrm{VI})$ (1) $0 \mathrm{mM}$ (control), (2) $0.1 \mathrm{mM}$, (3) $0.3 \mathrm{mM}$, (4) $0.5 \mathrm{mM}$, (5) $1 \mathrm{mM}$, (6) $1.5 \mathrm{mM}$ and (7) $1.8 \mathrm{mM}$; a $P$. ovata in agar-sucrose germination medium; $\mathbf{b}$ Measurement of shoot and root length on graph paper

\section{Atomic absorption spectroscopy}

The seedlings were uprooted from media after ten days of growth with intact roots. To avoid $\mathrm{Cr}$ cross-contamination from media while uprooting, the seedlings were washed with autoclaved double distilled water. The sample was then kept in a hot air oven at $70{ }^{\circ} \mathrm{C}$ overnight for drying. The dry tissue of the sample (100 mg) was digested for an overnight in a 1:1 solution of $\mathrm{HNO}_{3}$ and $\mathrm{H}_{2} \mathrm{O}_{2}$ [33]. The digested sample was then filtered through Whatman filter paper no. 41. The filtrate was allowed to evaporate by incubating at $90{ }^{\circ} \mathrm{C}$ using water bath. Then, the remaining filtrate was diluted to make a $6 \mathrm{ml}$ volume with $5 \% \mathrm{HNO}_{3}$ solution. Finally, the samples were filtered twice before measuring the absorbance at $357.8 \mathrm{~nm}$ in the Thermo
Fisher Scientific iCE 3000 series AA spectrometer with acetylene flame. The calibration curve was prepared with chromium standard of required concentration.

\section{Statistical analysis}

Experiments were carried out in triplicate and experimental data were expressed as mean \pm SEM (standard error of the mean). The Kyplot (version 2.0) was used to obtain the statistically significant data. Experimental data were analyzed by one-way analysis of variance (ANOVA) and significance of the data was analyzed by using the Student's t-test. A difference in experimental data at $p \leq 0.05$ was considered statistically significant.

\section{Results}

\section{Morphological analysis}

Morphological changes in the shoot and root length after exposure to $\mathrm{Cr}$ (VI) in the medium was quite evident (Fig. 1). The roots were more adversely affected than the shoots. At higher doses ( $1 \mathrm{mM}, 1.5 \mathrm{mM}, 1.8 \mathrm{mM})$, the shoot length was reduced below one fourth; whereas, the root length was drastically reduced below one twenty fifth compared to control (Fig. 2). Multiple root growth also occurred in the seedlings under low chromium stress (0.1 mM, $0.3 \mathrm{mM}$ and $0.5 \mathrm{mM}$ ) (Fig. 3). Though phenotypical changes due to $\mathrm{Cr}$ (VI) stress affected the shoot and root length, the seedlings seemed to be quite tolerant with respect to germination rate and multiple root growth up to $0.5 \mathrm{mM}$.

\section{Effect on seed germination}

Cr (VI) had no significant effect on germination of $P$. ovata seeds at least up to $1 \mathrm{mM}$, and over this concentration, the growth of seedlings was severely suppressed (Figs. 4 and 5). After two days incubation on tissue culture media, the seed germination percentage was reduced to $86 \%$ and $59 \%$ in $1.5 \mathrm{mM}$ and $1.8 \mathrm{mM}$ doses, respectively, compared to $95 \%$ in seeds grown without chromium stress.

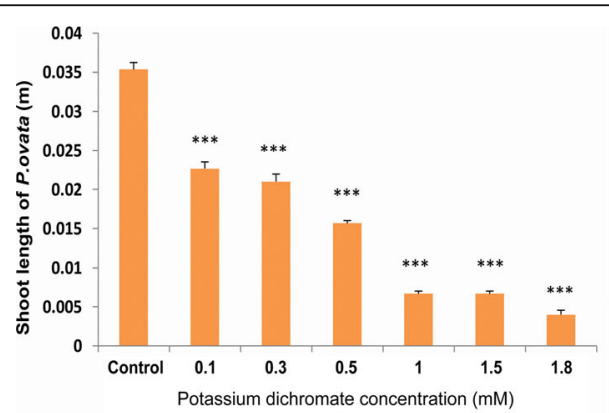

(a)

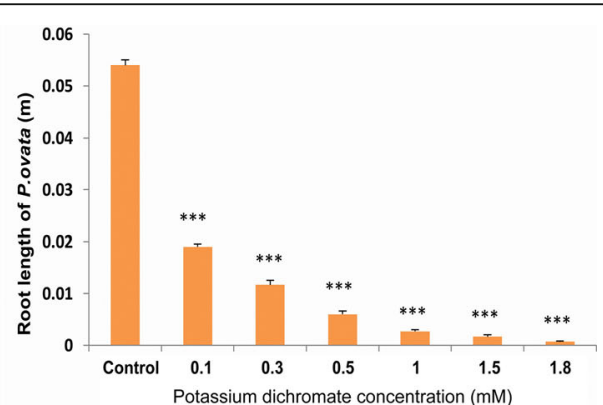

(b)

Fig 2 a Shoot length and $\mathbf{b}$ root length under $\mathrm{Cr}(\mathrm{VI})$ stress. The data are represented as mean \pm standard error of mean (SEM) $(n=5)$. Asterisks denote the level of significance; ${ }^{*} p \leq 0.05,{ }^{* *} p \leq 0.01,{ }^{* * *} p \leq 0.001$ 


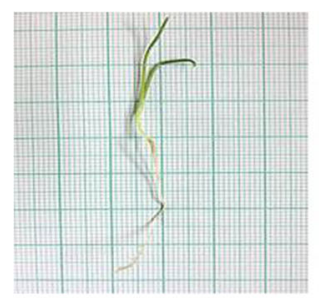

Control (0 mM)

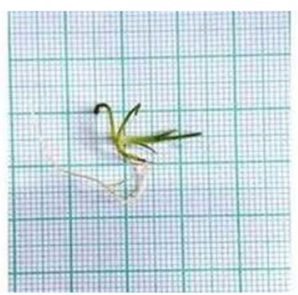

$0.1 \mathrm{mM}$

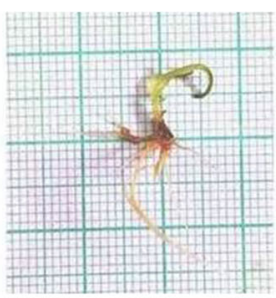

$0.3 \mathrm{mM}$

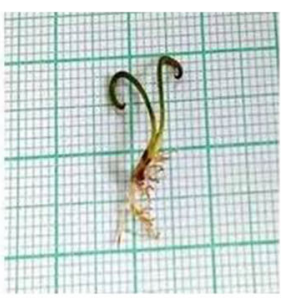

$0.5 \mathrm{mM}$

Fig. 3 Multiple root growth in 10 day-old $P$. ovata with $\mathrm{Cr}(\mathrm{VI})$ stress $(0.1 \mathrm{mM}, 0.3 \mathrm{mM}$ and $0.5 \mathrm{mM})$

\section{Effect on plant biomass}

Cr (VI) caused a negative impact on P. ovata biomass production (Fig. 6). The effect was drastic at $0.3 \mathrm{mM}$ dose, where fresh weight (FW) reduced by a half compared to the control seedlings. At the $\mathrm{Cr}$ (VI) concentrations higher than $0.3 \mathrm{mM}$, the FW gradually decreased. The dry weight (DW) also followed the same trend and was reduced to about $63 \%$ of the control. Percentage of water content, calculated from the FW and DW revealed that the water content decreased with the increase in the $\mathrm{Cr}$ (VI) concentrations (Fig. 7). Plants grown at the higher concentrations $(1.5 \mathrm{mM}$ and $1.8 \mathrm{mM}$ ) severely affected the water content in the tissue.

\section{Chlorophyll, carotenoid and total polyphenol contents}

Chlorophyll (a, b and total chlorophyll) and carotenoid contents in the seedlings increased significantly with $\mathrm{Cr}$ (VI) exposure up to $1.5 \mathrm{mM}$ concentration. The highest and lowest contents were found at $0.5 \mathrm{mM}$ and $1.8 \mathrm{mM}$ $\mathrm{Cr}$ (VI), respectively (Fig. 8). The carotenoid content also followed the same trend as the chlorophyll content (Fig. 9). At the concentrations above $0.5 \mathrm{mM}$, there was a steady decrease in the chlorophyll as well as carotenoid contents. The total polyphenol content increased approximately 3.8 times in the seedlings treated with $0.5 \mathrm{mM} \mathrm{Cr}(\mathrm{VI})$ compared to the control. The total polyphenol content was highest at $0.5 \mathrm{mM} \mathrm{Cr}$ (VI) (Fig. 10).

\section{Total antioxidant levels and DPPH radical scavenging activity}

Steady and significant increase in total antioxidant activity up to 3 times in $1.5 \mathrm{mM}$, as compared to the control, and then slightly declined at the highest $\mathrm{Cr}$ (VI) concentration $(1.8 \mathrm{mM})$ in the experiment (Fig. 11). Though total antioxidant content increased with the stress, DPPH radical scavenging activity, i.e., the percentage of free radical inhibition, did not increase as compared to the control. The reduction was significant, but very little up to $1 \mathrm{mM}$ of $\mathrm{Cr}$ (VI) dose (Fig. 12). Percentage of inhibition was $90.8 \%$ in control plant followed by $89.4,84.3,78.2$ and $83.7 \%$ with $\mathrm{Cr}$ (VI) dose of $0.1 \mathrm{mM}, 0.3 \mathrm{mM}, 0.5 \mathrm{mM}$, and

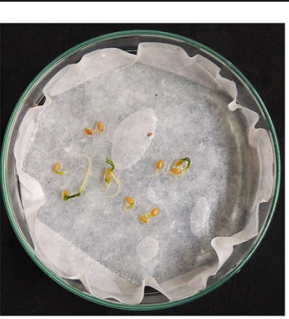

Control (0 mM)

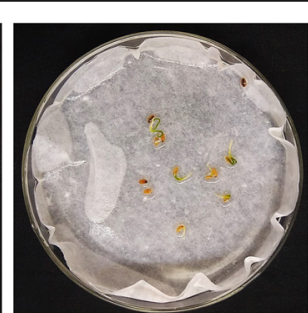

$0.1 \mathrm{mM}$

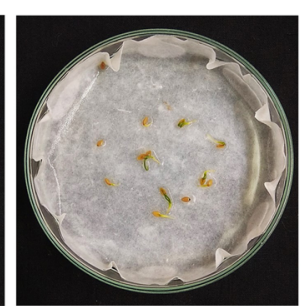

$0.3 \mathrm{mM}$

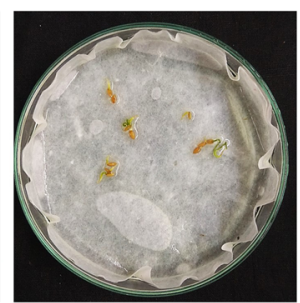

$0.5 \mathrm{mM}$

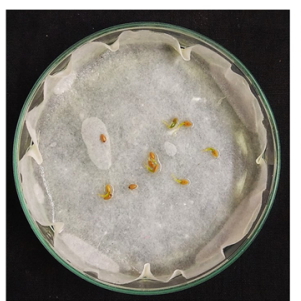

$1 \mathrm{mM}$

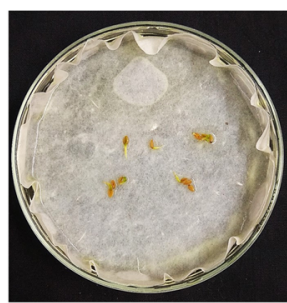

$1.5 \mathrm{mM}$

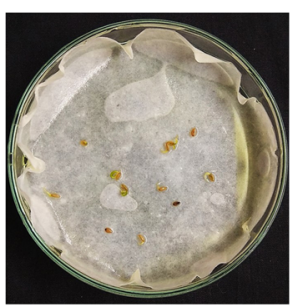

$1.8 \mathrm{mM}$

Fig. 4 Picture of $P$. ovata seeds with different doses of $\mathrm{Cr}(\mathrm{VI})$ (1) $0 \mathrm{mM}$ (control), (2) $0.1 \mathrm{mM}$, (3) $0.3 \mathrm{mM}$, (4) $0.5 \mathrm{mM}$, (5) $1 \mathrm{mM}$, (6) $1.5 \mathrm{mM}$ and (7) $1.8 \mathrm{mM}$ after $48 \mathrm{~h}$ of germination period 


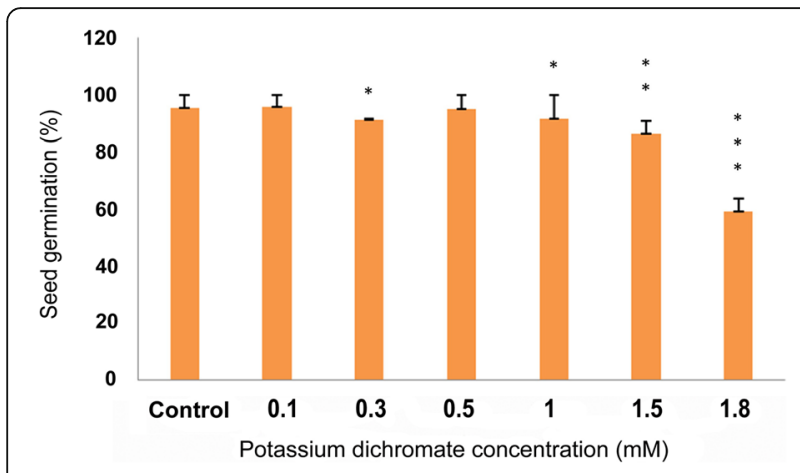

Fig. 5 Seed germination percentage of $P$. ovata with $48 \mathrm{~h}$ after $\mathrm{Cr}(\mathrm{VI})$ stress. The data are represented as mean \pm standard error of mean (SEM) $(n=5)$. Asterisks denote the level of significance; ${ }^{*} p \leq 0.05,{ }^{* *} p \leq 0.01,{ }^{* *} p \leq 0.001$

$1 \mathrm{mM}$, respectively. At the concentrations $1.5 \mathrm{mM}$ and $1.8 \mathrm{mM}$, the inhibition decreased sharply to $56.8 \%$ and $68.1 \%$ respectively.

\section{Lipid peroxidation levels}

The MDA content indicating the lipid peroxidation level, was significantly low in the seedlings exposed to $\mathrm{Cr}$ (VI) stress. The peroxidation level decreased to one half in all the $\mathrm{Cr}$ (VI) treated seedlings ( 0.1 to $1.8 \mathrm{mM}$ ), as compared to the control seedlings (Fig. 13).

\section{PAL and PPO activities}

PAL activity assay was carried out to measure the changes in the concentration of PAL enzyme in the seedlings treated with various $\mathrm{Cr}(\mathrm{VI})$ concentrations, and the result was expressed as $\mu \mathrm{mol}$ trans-cinnamic acid $\min ^{-1} \mathrm{~g}^{-1}$ fresh weight (FW) of callus. PAL activity increased gradually from $0.3 \mathrm{mM}$ that is 1.8 times higher than the control level, and saturated at $1.5 \mathrm{mM}$ and above (Fig. 14).

PPO activity assay was carried out to measure the amount of PPO enzyme in the samples at the various $\mathrm{Cr}$ (VI) concentrations, and the result was expressed as absorbance units (AU) $\mathrm{min}^{-1} \mathrm{~g}^{-1}$ fresh weight of shoot tissue. The PPO activity became maximum at $0.3 \mathrm{mM}$ that is 3.6 times higher than the activity of the control (Fig. 15), and then the activity gradually dropped down to the control levels till $1.8 \mathrm{mM}$.

\section{$P A L$ and $P P O$ gene expressions}

Phenylalanine ammonia lyase $(P A L)$ gene expression was significantly upregulated in the seedlings treated with $\mathrm{Cr}$ (VI). RT-PCR band intensity was enhanced with increasing $\mathrm{Cr}$ (VI) concentrations. The $P A L$ gene expression was highest at $1 \mathrm{mM} \mathrm{Cr}$ (VI) of which intensity was 1.4-fold compared to control (Fig. 16).

Expression of polyphenol oxidase $(P P O)$ gene, an antioxidative enzyme gene responsive to the heavy metals, was also upregulated with Cr (VI) treatment (Fig. 17) [2, 11]. The upregulation was highest at $1 \mathrm{mM} \mathrm{Cr}$ (VI) of which expression was 1.6-fold compared with the control.

\section{Chromium accumulation}

Chromium accumulation in shoot and root of $P$. ovata shoots and roots was enhanced with increasing $\mathrm{Cr}$ (VI) concentration in the germination medium (Fig. 18). Control shoot tissues devoid of $\mathrm{Cr}$ (VI) in the medium contained $0.27 \mathrm{ppm} \mathrm{Cr}(\mathrm{VI})$, while $0.1 \mathrm{mM}(29.4 \mathrm{mg} / \mathrm{L})$ $\mathrm{Cr}$ (VI) treated seedlings, showed increased $\mathrm{Cr}$ accumulation by 2.9 times in the shoot. The accumulation of $\mathrm{Cr}$ (VI) increased by 147.6 times of the control. In the control root tissues, the $\mathrm{Cr}(\mathrm{VI})$ content was $0.93 \mathrm{ppm}$ that was higher than the $\mathrm{Cr}(\mathrm{VI})$ content found in the control shoots. Accumulation of $\mathrm{Cr}$ (VI) in the root also increased in a dose-dependent manner with increasing $\mathrm{Cr}$ (VI) concentrations in the culture medium. With $0.5 \mathrm{mM}$ $\mathrm{Cr}$ (VI) treatment, its accumulation in the roots increased by 15.6 times of the control.

\section{Discussion}

Heavy metal stress induces an alteration in many physiological processes and affects many biochemical pathways

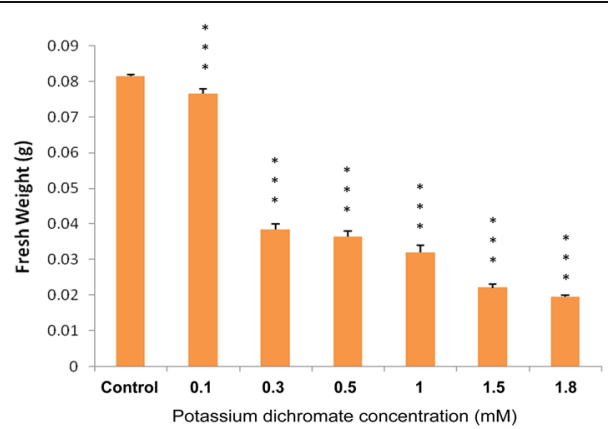

(a)

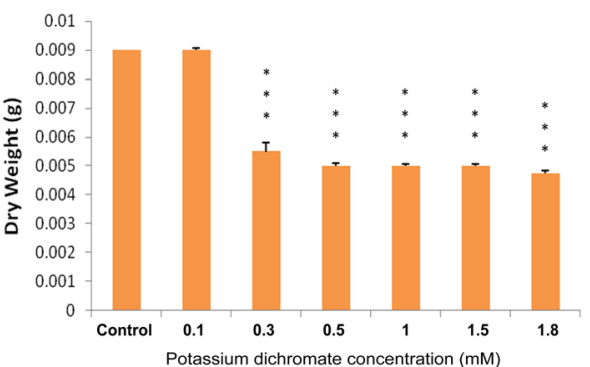

(b)

Fig. $\mathbf{6}$ a Fresh weight and $\mathbf{b}$ dry weight of $P$. ovata with $\mathrm{Cr}(\mathrm{VI})$ stress after 10 days of growth. The data are represented as mean \pm standard error of mean (SEM) $(n=5)$. Asterisks denote the level of significance; ${ }^{*} p \leq 0.05,{ }^{* *} p \leq 0.01,{ }^{* *} p \leq 0.001$ 


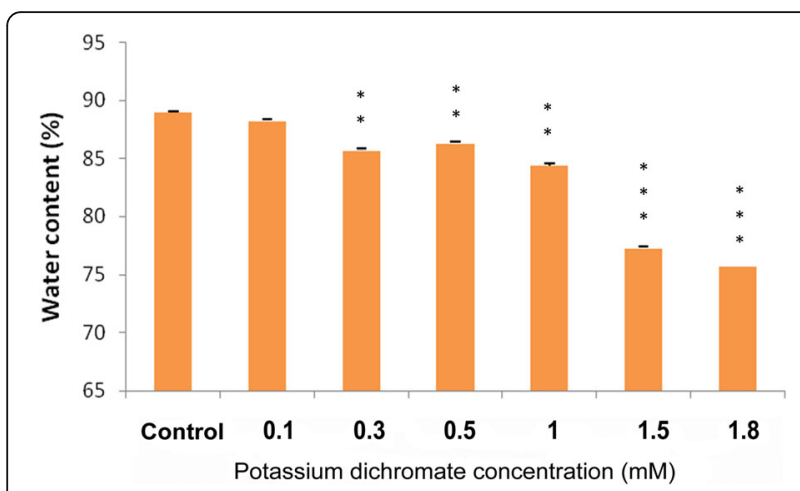

Fig. 7 Water content (\%) in P. ovata with $\mathrm{Cr}(\mathrm{VI})$ stress after 10 days of growth. The data are represented as mean \pm standard error of mean (SEM) $(n=5)$. Asterisks denote the level of significance; ${ }^{*} p \leq 0.05,{ }^{* *} p \leq 0.01,{ }^{* *} p \leq 0.001$

resulting in decrease or increase in production of various metabolic compounds. Like other heavy metals, potassium dichromate $(\mathrm{Cr} \mathrm{VI})$ treatment resulted in significant reduction of the shoot and root length in 10 day-old $P$. ovata seedlings in a dose-dependent manner (Fig.1). High doses of Cr (VI) stress mainly affected the radical growth in $P$. ovata, similar to the findings by other investigators [1, 34]. Root growth was mainly affected through tissue damage which hindered water and nutrient absorption from the media containing Cr (VI) [1, 35]. In spite of reduction in root length, it should be noted that multiple root development was found in $P$. ovata with $0.1-0.5 \mathrm{mM} \mathrm{Cr}$ (VI) concentrations (Fig. 3), which have been found previously in Cr (VI)-treated alfalfa plants [1, 36]. Root growth affects biomass, length, amount and rate of elongation of plants depending on the tolerable or toxic levels of heavy metals in the soil [37]. In P. ovata, the shoot length and root length decreased with increasing $\mathrm{Cr}$ (VI) concentrations (Fig. 2), which would be due to

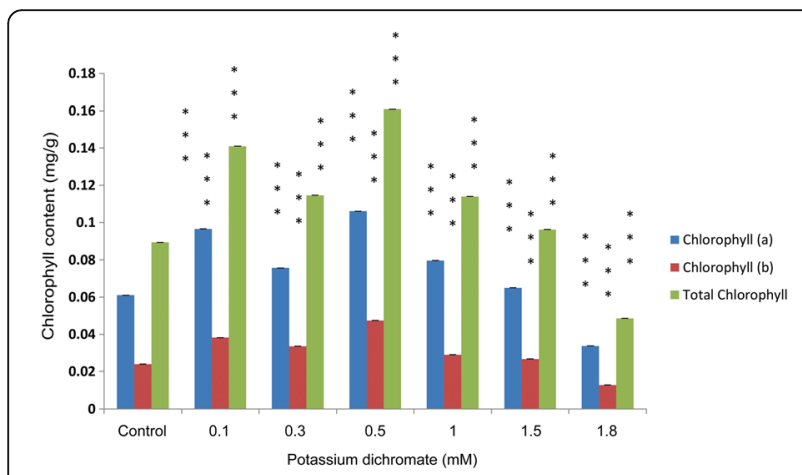

Fig. 8 Chlorophyll a, b and total chlorophyll content in 10 day-old $P$. ovata with $\mathrm{Cr}(\mathrm{VI})$ stress. The data are represented as mean \pm standard error of mean (SEM) $(n=5)$. Asterisks denote the level of significance; ${ }^{*} p \leq 0.05,{ }^{* *} p \leq 0.01,{ }^{* *} p \leq 0.001$

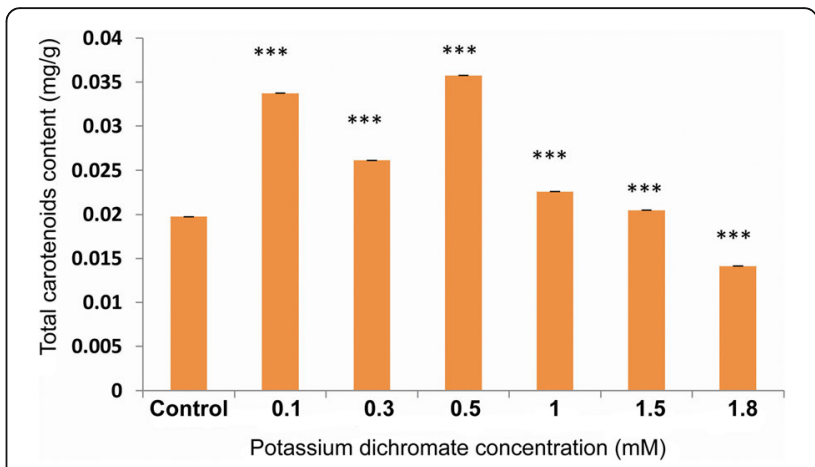

Fig. 9 Total carotenoid content in 10 day-old $P$. ovata under $\mathrm{Cr}(\mathrm{VI})$ stress. The data are represented as mean \pm standard error of mean $(\mathrm{SEM})(n=5)$. Asterisks denote the level of significance; ${ }^{*} p \leq 0.05$, ${ }^{* *} p \leq 0.01,{ }^{* * *} p \leq 0.001$

the inhibition of cell division possibly by inducing chromosomal aberrations, as observed by Liu et al. [38]. Seed germination was not affected significantly at the low concentrations of $\mathrm{Cr}$ (VI) (Figs. 4 and 5). Increase in various factors such as $\alpha$-amylase, an enzyme involved in seed germination to supply sugar, may block the adverse effects of low doses of $\mathrm{Cr}$ (VI) on the seed germination [39]. The rate was affected by only above $1 \mathrm{mM}$, wherein it decreased by 1.5 times at the highest dose $(1.8 \mathrm{mM})$.

The fresh weight of the plant tissue was severely affected by the treatment with $\mathrm{Cr}(\mathrm{VI})$, which reduced severely even at lower concentrations (Fig. 6). Our results are consistent with the results of Wyszkowski et al. [40], which shows that the biomass of spring barley decreased; with an increase in the $\mathrm{Cr}$ content. These results might imply that the reduction in the content of the vital pigments inhibits the growth of the plant. Water content also decreased (Fig. 7), which is quite evident from the fact that the roots were severely affected by $\mathrm{Cr}(\mathrm{VI})$, and thus, they

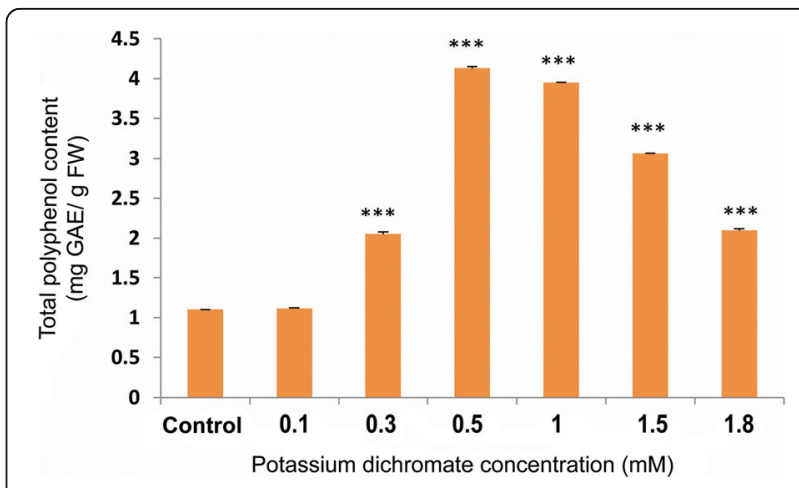

Fig. 10 Total polyphenol content in 10 day-old $P$. ovata under $\mathrm{Cr}$ (VI) stress. The data are represented as mean \pm standard error of mean (SEM) $(n=5)$. Asterisks denote the level of significance; ${ }^{*} p \leq 0.05,{ }^{* *} p \leq 0.01,{ }^{* * *} p \leq 0.001$ 


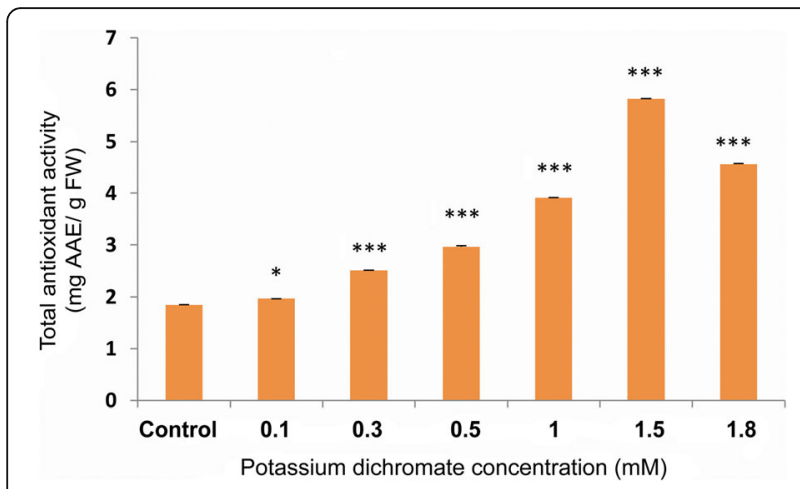

Fig. 11 Total antioxidant activity in 10 day-old $P$. ovata with $\mathrm{Cr}(\mathrm{VI})$ stress. The data are represented as mean \pm standard error of mean $(\mathrm{SEM})(n=5)$. Asterisks denote the level of significance; ${ }^{*} p \leq 0.05$, ${ }^{* *} p \leq 0.01,{ }^{* * *} p \leq 0.001$

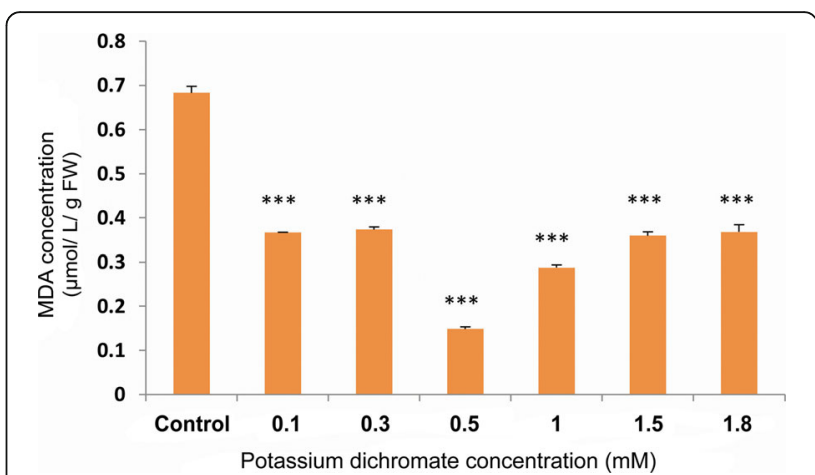

Fig. 13 Lipid peroxidation levels with $\mathrm{Cr}(\mathrm{VI})$ stress exposure in 10 day-old $P$. ovata. The data are represented as mean \pm standard error of mean (SEM) $(n=5)$. Asterisks denote the level of significance; ${ }^{*} p \leq 0.05,{ }^{* *} p \leq 0.01,{ }^{* * *} p \leq 0.001$ impaired further water absorption and transport from the culture media.

Heavy metal stress affects various growth parameters like, inhibiting physiological processes by hampering pigment formation and degrading chloroplast ultrastructure. Chromate has been known to influence the enzymes of the Calvin cycle and was even used as a Hill reagent $[9,41,42]$. Here in $P$. ovata, chlorosis was not observed at the low concentrations of $\mathrm{Cr}$ (VI), thus, showing a significant increase in total chlorophyll formation, i.e., 1.8 times with $0.5 \mathrm{mM} \mathrm{Cr}$ (VI) to that of the control seedlings (Figs. 8 and 9). Subsequently in the present investigation, chlorophyll a, b and carotenoid contents increased in the seedling tissue. The results are quite different from majority of other documented findings that showed that even lower doses of $\mathrm{Cr}$ stress affected the pigment formation and formed chlorosis

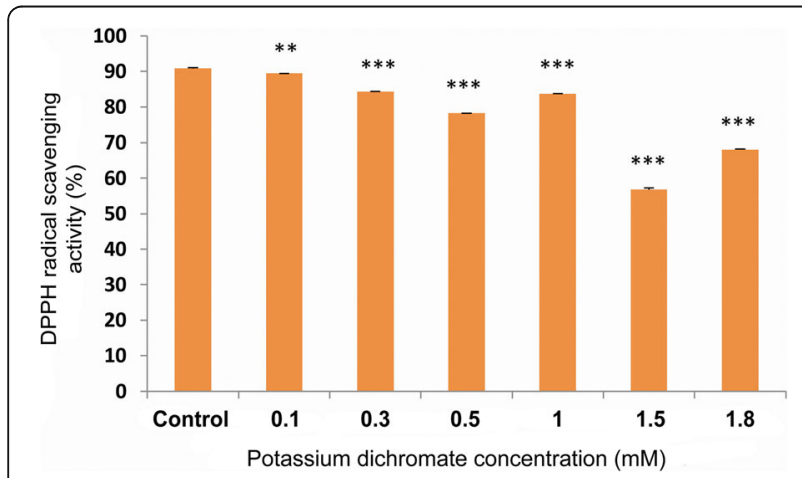

Fig. 12 Percentage of DPPH radical scavenging activity in 10 day-old $P$. ovata with $\mathrm{Cr}(\mathrm{VI})$ stress, where, 100\% DPPH radical scavenging activity refers to inhibition of all the free radicals by the sample. The data are represented as mean \pm standard error of mean (SEM) $(n=5)$. Asterisks denote the level of significance; ${ }^{*} p \leq 0.05$, ${ }^{* *} p \leq 0.01,{ }^{* * *} p \leq 0.001$ like in Nymphaea alba L. [5] and Oryza sativa L. [10]. But leaves and stems of some plants like Jatropha curcas, showed elevated chlorophyll a content along with chlorophyll b, total chlorophyll, and carotenoid under 50 and $100 \mathrm{mg} / \mathrm{kg} \mathrm{Cr}$ stress. Similarly, Plantago arenaria did not show any sign of chlorosis or wilting under the heavy metal stress like $\mathrm{Cu}, \mathrm{Zn}, \mathrm{Cd}$, and $\mathrm{Ni}$ and is found to have tolerance against heavy metals stress [19]. P. ovata seedlings also showed such adaptive response via pigment restoration and formation, up to certain level of $\mathrm{Cr}(\mathrm{VI})$ concentration, implying the increase in the chlorophyll content as a plant defence responses against the stress.

Total polyphenol content was also enhanced by 3.8 times in $P$. ovata seedlings when treated with $0.5 \mathrm{mM}$ $\mathrm{Cr}$ (VI) concentration, with respect to the untreated set (Fig. 10). Polyphenols are a group of plant secondary

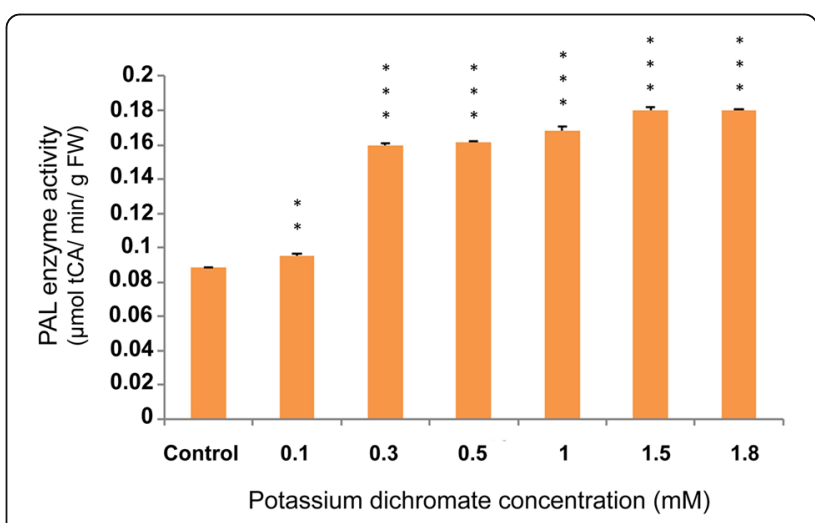

Fig. $14 \mathrm{PAL}$ activity assay with $\mathrm{Cr}(\mathrm{VI})$ stress exposure in 10 day-old $P$. ovata. The data are represented as mean \pm standard error of mean (SEM) $(n=5)$. Asterisks denote the level of significance; ${ }^{*} p \leq 0.05$, ${ }^{* *} p \leq 0.01,{ }^{* * *} p \leq 0.001$ 


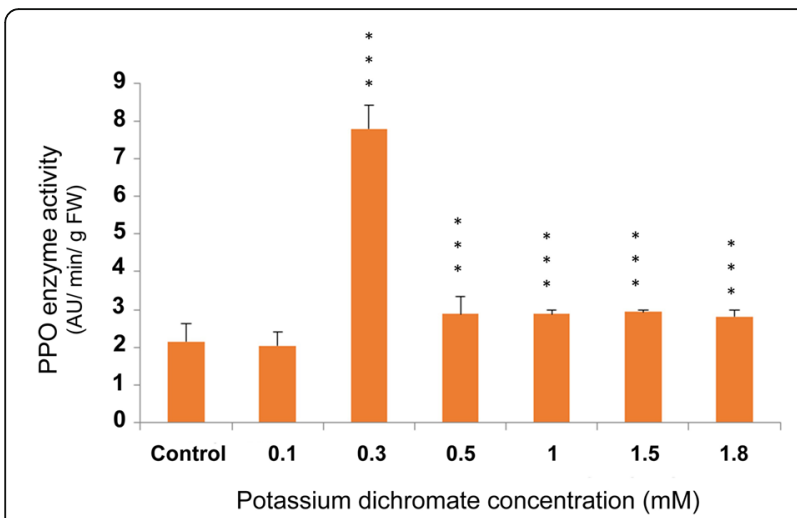

Fig. 15 PPO activity assay with $\mathrm{Cr}(\mathrm{VI})$ stress exposure in 10 day-old $P$. ovata. The data are represented as mean \pm standard error of mean (SEM) $(n=5)$. Asterisks denote the level of significance; ${ }^{*} p \leq 0.05$, ${ }^{* *} p \leq 0.01,{ }^{* * *} p \leq 0.001$

metabolites which are known to be accumulated as a part of stress response, thus, making the plant capable of withstanding any harsh condition [12, 43]. In the varieties of Catharanthus roseus, secondary metabolites like vincristine and vinblastine were enhanced by $\mathrm{Cr}$ stress [44], but the effect of $\mathrm{Cr}$ on polyphenol content has not been investigated much. Increase in the polyphenol content under other heavy metal stresses was quite evident in various studies. In Jatropha curcas, $\mathrm{Pb}$ and $\mathrm{Cr}$ treatment enhanced the phenolic content in all parts of the plant [2]. Also, in a recent study, $\mathrm{Cd}$ treatment on Gynura procumbens resulted in enhanced phenolic

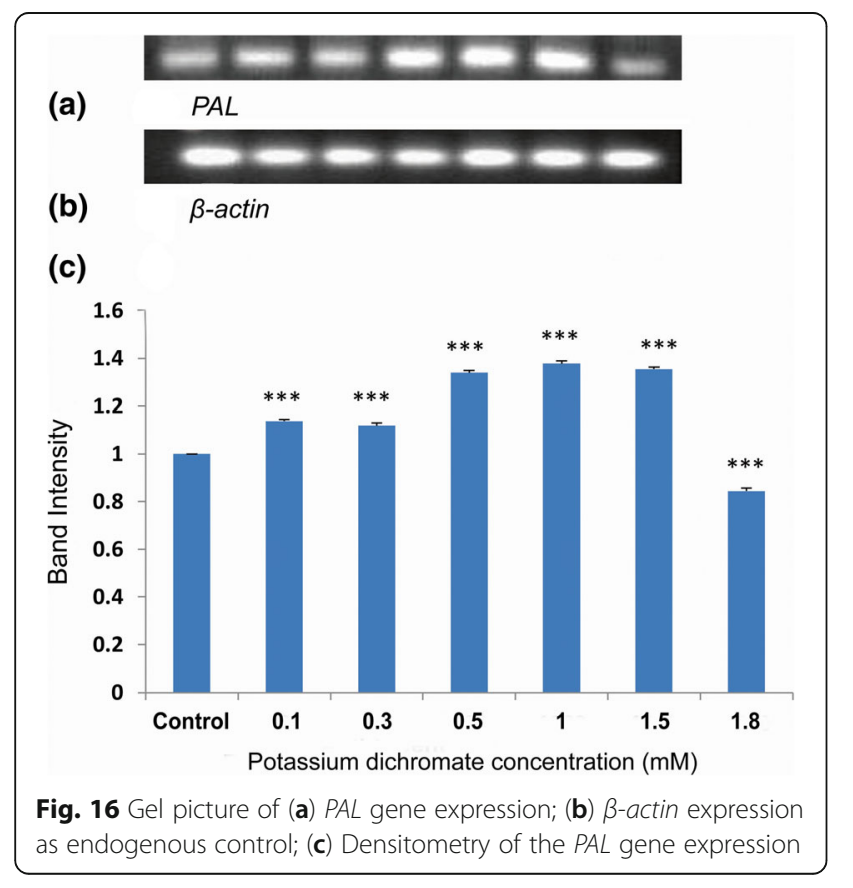

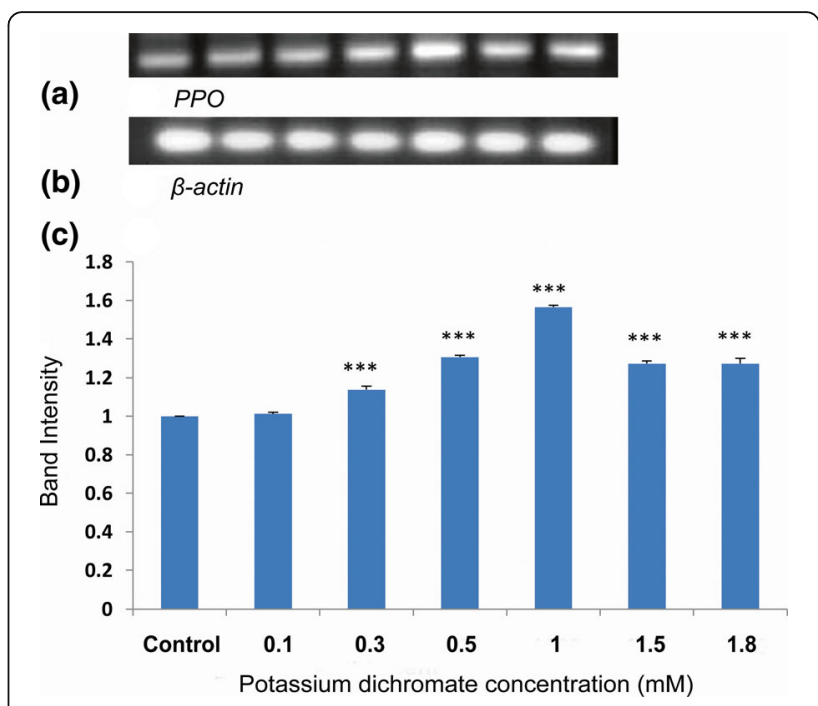

Fig. 17 Gel picture of (a) PPO gene expression; $\mathbf{b} \beta$-actin expression as the endogenous control; $\mathbf{c}$ Densitometry of the PPO gene expression

accumulation [45]. Moderate $\mathrm{Cd}$ dose affected the growth parameters in $H$. hemerocallidea along with an increase in the polyphenol accumulations, though low Al levels did not have any affect [43]. These results including our data suggest that polyphenol accumulation is the outcome of the plant's robust mechanism to fight and adapt against the metal stress.

Total antioxidant activity of $P$. ovata was enhanced by $\mathrm{Cr}$ (VI) stress by 3.2 times with $1.5 \mathrm{mM}$ (Fig. 11). In camomile plants, excess $\mathrm{Cr}$ treatment caused increase in antioxidant enzyme and ascorbic acid content [46]. In Sorghum bicolour $\mathrm{L}$., $\mathrm{Al}$ treatment caused increase in antioxidants like glutathione (GSH) [47]. Therefore, it can be inferred that increased total antioxidant levels as well as total polyphenol content depict an adaptive behaviour of $P$. ovata against $\mathrm{Cr}$ (VI) stress.

There was a significant decrease in total free radical scavenging activity with increasing concentration of $\mathrm{Cr}$ (VI) stress in P. ovata (Fig. 12) due to generation of free radicals. Plants generate various secondary metabolites that can act as antioxidants [48], but the synergistic effects of these antioxidants are not always enough to quench the free radical pool. Thus, plants are trying to combat the stress to some extent but not completely, resulting in morphological alterations like reduction in shoot and root length. Lipid peroxidation of cell membrane is also free radical damage generated by the heavy metal stress. MDA forms as an oxidized product of the polyunsaturated fatty acid present in the membranes of cells, and so, its content acts as an indicator of the oxidative damage $[29,49]$. The MDA content was found to be low in $\mathrm{Cr}(\mathrm{VI})$ treated seedlings when compared to 


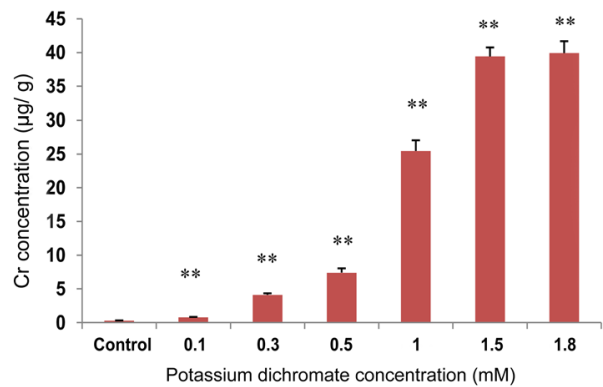

(a)

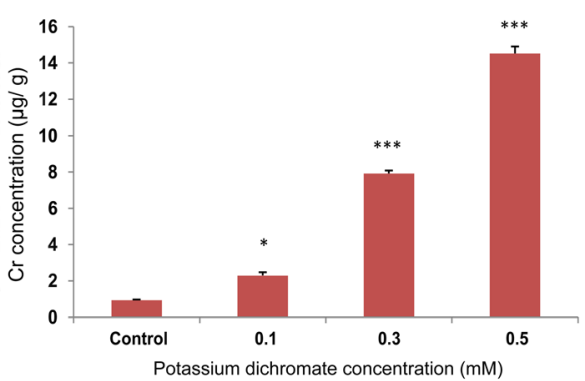

(b)

Fig. 18 Chromium accumulations in 10 day-old $P$. ovata (a) shoot and (b) root, measured by AAS. The data are represented as mean \pm standard error of mean (SEM) $(n=5)$. Asterisks denote the level of significance; ${ }^{*} p \leq 0.05,{ }^{* *} p \leq 0.01,{ }^{* *} p \leq 0.001$

the control group, which is quite similar to the findings that lipid peroxidation levels of Cajanus cajan L. decrease with an increase in antioxidant enzyme activity [50]. These results might suggest that the membrane damage by free radical generation was not prominent possibly due to the increase in the total antioxidant levels in P. ovata (Fig. 13).

Polyphenol oxidase (PPO) and Phenylalanine ammonia lyase $(P A L)$ gene expressions along with their enzyme activity elevated with an increase in $\mathrm{Cr}(\mathrm{VI})$ concentration in $P$. ovata seedlings. There was a 1.6 -fold increase in $P P O$ gene expression with $1 \mathrm{mM} \mathrm{Cr}(\mathrm{VI})$, which is the highest increase among other concentrations (Fig. 17). PPO enzyme activity also followed the similar trend with its gene expression (Fig. 15). Polyphenol oxidase has a role in plant defence response against various abiotic stresses [51], and so, the upregulation in the expression of the PPO gene expression may have played an important role in $P$. ovata adaptive response against $\mathrm{Cr}$ (VI) stress. Similar results were found in Jatropha curcus L., where polyphenol oxidase activity was elevated by $\mathrm{Cr}$ (VI) treatment [2]. PAL is one of the key enzymes with a vital role in the phenylpropanoid pathway, and catalyzes the initial step in the synthesis of various plant secondary metabolites. So, change in the PAL gene expression due to heavy metal stress was already corroborated in various literatures. In our study, elevation of $P A L$ gene expression and its enzyme activity by $\mathrm{Cr}$ (VI) stress was found in P. ovata (Figs. 14 \& 16). In other studies, the elevation of $P A L$ activity by $\mathrm{Cr}$ (VI) and $\mathrm{Al}$ (III) stresses was found in Jatropha curcus L. and Sorghum bicolor, respectively [2, 47].

In this study, $P$. ovata was found to be more or less tolerant to chromium (VI) stress, which was evident from the increase in plant secondary metabolites [52], total antioxidant activity, reduction in lipid peroxidation along with upregulation in PPO and PAL gene expressions as well as its enzyme activity under chromium (VI) application. These results support the fact that, the plant tries to quench the ROS generation using secondary metabolite production to combat the stress. The quantity of
Cr uptake in $P$. ovata was not comparable to other $\mathrm{Cr}$ hyperaccumulators (Fig. 18). At $1 \mathrm{mM} \mathrm{Cr}$ (VI), P. ovata accumulated $25.4 \mathrm{ppm}$ (or $25.4 \mathrm{mg} / \mathrm{kg}$ ) $\mathrm{Cr}$ in the shoot, which is about $8.3 \%$ of the total metal concentration given in the medium. At $1.8 \mathrm{mM} \mathrm{Cr}$ dose, the uptake was $40 \mathrm{ppm}$ (or $40 \mathrm{mg} / \mathrm{kg}$ ). This result may depict similarity in $\mathrm{Cr}$ accumulation capacity of other Plantago species, $P$. algarbiensis, $P$. almogravensis, $P$. holosteum, P. alpina, $P$. maritime, P. coronopus, $P$. serraria, $P$. asiatica, P. major, $P$. australis, $P$. afra, $P$. arenaria, $P$. bellardii, $P$. lagopus and P. lanceolata [18]. The magnitude of $\mathrm{Cr}$ (VI) uptake of Plantago would be poor compared to Leersia hexandra Swartz, a hyperaccumulator of Cr [53].

Though $\mathrm{Cr}$ pollution is pertinent in soils of Gujarat near industrial area, $P$. ovata grows in agricultural fields, where $\mathrm{Cr}$ contamination is low. This study gave us information of the plant's behaviour in the presence of $\mathrm{Cr}$ (VI) stress and provided us with an outlook of measures to take care of the polluted soil before cultivating $P$. ovata.

\section{Conclusion}

The present study on $P$. ovata under the presence of $\mathrm{Cr}$ (VI) gave us important insights about how the plant system deals with the stress. Increase in plant secondary metabolites, total antioxidant levels, upregulation of $P A L$ and PPO genes as well as the enzymatic activity in the plant depict the survival strategy and response towards the increase in $\mathrm{Cr}$ (VI) stress, thus reinforcing that these metabolites and genes play to combat the stress. This study will help us to elucidate the target secondary metabolic pathway for the plant defence response against such the heavy metal stress.

\section{Additional file}

Additional file 1: Table S1. Designed primers for sequencing of PPO gene. Table S2. PCR conditions of PPO gene amplification for sequencing. Table S3. Primers for expression analysis. Table S4. Reaction conditions for expression analysis. (DOCX $15 \mathrm{~kb}$ ) 


\section{Abbreviations}

$\mathrm{Cr}(\mathrm{VI})$ : Hexavalent chromium; Cr: Chromium; DPPH: 1, 1-diphenyl-2-picrylhydrazyl; MDA: Malondialdehyde; PAL: Phenylalanine ammonia lyase; PPO: Polyphenol oxidase; TBARS: Thiobarbituric reactive substance

\section{Acknowledgements}

UGC Major Research project [F.41-508/2012(SR)] for funding assistance is acknowledged.

\section{Funding}

Funding by University Grants Commission, Ref No- 41-508/2012(SR).

\section{Authors' contribution}

The first author carried out all the experiments. The second author carried out experiments of seed germination percentage, PAL and PPO enzyme activity (these new experiments were suggested by the reviewers). The corresponding author has planned the manuscript writing and correction. All authors read and approved the final manuscript.

\section{Ethics approval and consent to participate}

Not applicable.

\section{Consent for publication}

Not applicable.

\section{Competing interests}

The authors have no competing interests.

\section{Publisher's Note}

Springer Nature remains neutral with regard to jurisdictional claims in published maps and institutional affiliations.

\section{Received: 14 December 2017 Accepted: 19 September 2018} Published online: 15 October 2018

\section{References}

1. Oliveira $\mathrm{H}$. Chromium as an environmental pollutant: insights on induced plant toxicity. Journal of Botany. 2012. https://doi.org/10.1155/2012/375843.

2. Devi Chinmayee M, Anu M, Mahesh B, Mary S, Mini I, Swapna TS. A comparative study of heavy metal accumulation and antioxidant responses in Jatropha curcas L. IOSR J Environ Sci Bull Food Technol. 2014;8(7):58-67.

3. Mohanty M, Patra HK. Attenuation of chromium toxicity by bioremediation technology. In: Whitacre $D$, editor. Reviews of environmental contamination and toxicology, vol. 210; 2011. p. 1-34.

4. Rai V, Vajpayee $P$, Singh SN, Mehrotra S. Effect of chromium accumulation on photosynthetic pigments, oxidative stress defense system, nitrate reduction, proline level and eugenol content of Ocimum tenuiflorum L. Plant Sci. 2004;167:1159-69.

5. Vajpayee P, Tripathi RD, Rai UN, Ali MB, Singh SN. Chromium (VI) accumulation reduces chlorophyll biosynthesis, nitrate reductase activity and protein content in Nymphaea alba L. Chemosphere. 2000;41:1075-82.

6. Blacksmith institute. New York. www.pureearth.org/project/hema-chemicals/ (1999). Accessed 11 Jun 2018.

7. Krishna AK, Govil PK. Soil contamination due to heavy metals from an industrial area of Surat, Gujarat, Western India. Environ Monit Assess. 2007; $124: 263$

8. Sharma P, Bihari V, Agarwal SK, Verma V, Kesavachandran CN, Pangtey BS, Mathur N, Singh KP, Srivastava M, Goel SK. Groundwater contaminated with hexavalent chromium $[\mathrm{Cr}(\mathrm{VI})]$ : a health survey and clinical examination of community inhabitants (Kanpur, India). PLoS One. 2012;7(10):e47877.

9. Shanker AK, Cervantes C, Loza-Tavera H, Avudainayagam S. Chromium toxicity in plants. Environ Int. 2005;31:739-53.

10. Hadif WM, Rahim SA, Sahid I, Rahman A, Ibrahim I. Influence of chromium metal on chlorophyll content in leaves of paddy Oryza sativa L. Int J ChemSci. 2015;13(3).

11. Sangwan $P$, Kumar $V$, Joshi UN. Effect of chromium $(\mathrm{VI})$ toxicity on enzymes of nitrogen metabolism in Clusterbean (Cyamopsis tetragonoloba L). Enzyme Research. 2014. https://doi.org/10.1155/2014/784036.

12. Shukla OP, Dubey S, Rai UN. Preferential accumulation of cadmium and chromium: toxicity in Bacopa monnieri L. under mixed metal treatments. Bull Environ Contam Toxicol. 2007;78(3-4):252-7.
13. Goud PB, Kaechole MS. Antioxidant enzyme changes in neem, Pigeonpea, and mulberry leaves in two stages of maturity. Plant Signaling and Behavior. 2012;7:1258-62

14. Akula R, Ravishankar GA. Influence of abiotic stress signals on secondary metabolites in plants. Plant Signal Behav. 2011;6(11):1720-31.

15. Ross IA. Medicinal plants of the world Vol. 3. In: Humana Press; 2010.

16. Singh B. Psyllium as therapeutic and drug delivery agent. Int J Pharm. 2007; 334:1-4.

17. Dhar MK, Kaul S, Sareen S, Koul AK. Plantago ovata: genetic diversity, cultivation, utilization and chemistry. Plant Genetic Resources. 2005;3(2): 252-63.

18. Serrano HC, Cotrim H, Pinto MJ, Loucao MAM. Metal hyperaccumulation patterns within Plantago phylogeny (Plantaginaceae). Plant Soil. 2017;411(1): 227-41.

19. Remon E, B Ouchardon JL, Faure O. Multi-tolerance to heavy metals in Plantago arenaria Waldst. \& kit.: adaptive versus constitutive characters. Chemosphere. 2007:69:41-7.

20. Khan Zl, Kashaf S, Ahmad K, Akram NA, Ashraf M, Mahmood SU, Sohail M, Bashir H, Mehmood N. Metal uptake by psyllium (Plantago ovata L.) treated with lead (Pb) under semi-arid conditions. Legume Res. 2017:40(2):277-81.

21. Das Pal M, Sen Raychaudhuri S. Enhanced development of somatic embryos of Plantago ovata Forsk. By additives. In Vitro Cell Dev Biol. 2001; 37(5):568-71.

22. Singleton VL, Orthofer R, Lamuela-Raventos RM. Analysis of total phenols and other oxidation substrates and antioxidants by means of FolinCiocalteu reagent. Methods Enzymol. 1999;299:152-78.

23. Prieto $P$, Pineda M, Aguilar M. Spectrophotometric quantitation of antioxidant capacity through the formation of a phosphomolybdenum complex: specific application to the determination of vitamin E. Anal Biochem. 1999:269(2):337-41.

24. Talukder P, Talapatra S, Ghoshal N, Sen Raychaudhuri S. Antioxidant activity and high-performance liquid chromatographic analysis of phenolic compounds during in vitro callus culture of Plantago ovata Forsk and effect of exogenous additives on accumulation of phenolic compounds. J Sci Food Agric. 2015;96:232-44.

25. Sestak Z, Catský J, Jarvis PG. Plant photosynthetic production. Manual of methods. In: Plant photosynthetic production; 1971.

26. Lichtenthaler HK. Chlorophylls and carotenoids: pigments of photosynthetic biomembranes. Methods Enzymol. 1987:350-82.

27. Brand-Williams W, Cuvelier ME, Berset C. Use of a free radical method to evaluate antioxidant activity. Lebensm-Wiss Technol - Food Sci Technol. 1995;28(1):25-30.

28. Vasilaki AT, McMillan DC. Lipid peroxidation. In: Schwab M, editor. Encyclopedia of cancer. Springer. Heidelberg: Berlin; 2011.

29. Heath RL, Packer L. Photoperoxidation in isolated chloroplasts. I Kinetics and stoichiometry of fatty acid peroxidation Arch Biochem Biophys. 1968;125(1): 189-98.

30. Kovacik J, Klejdus B. Tissue and method specificities of phenylalanine ammonia-lyase assay. J Plant Physiol. 2012;169(13):1317-20.

31. Arnnok P, Ruangviriyachai C, Mahachai R, Techawongstien S, Chanthai S. Optimization and determination of polyphenol oxidase and peroxidase activities in hot pepper (Capsicum annuum L.) pericarb. Int. food res. J. 2010; 17(2):385-92.

32. Edwards K, Johnstone C, Thompson C. A simple and rapid method for the presentation of plant genomic DNA for PCR analysis. Nucleic Acids Res. 1991;19(6):1349.

33. Siaka M, Owens CM, Birch GF. Evaluation of some digestion methods for the determination of heavy metals in sediment samples by flame-AAS. Anal Lett. 2006;31(4):703-18.

34. Corradi MG, Bianchi A, Albasini A. Chromium toxicity in salvia sclarea-I. effects of hexavalent chromium on seed germination and seedling development. Environ Exp Bot. 1993;33(3):405-13.

35. Barcelo J, Poschenrieder C, Gunse J. Effect of chromium VI on mineral element composition of bush beans. J Plant Nutr. 1985:8(3):211-7.

36. Peralta JR, Gardea-Torresdey JL, Tiemann KJ, Gomez E, Arteaga S, Rascon E, Parsons JG. Uptake and effects of five heavy metals on seed germination and plant growth in alfalfa (Medicago sativa L.). Bull Environ Contam Toxicol. 2001:66(6):727-34

37. Baker AJ, Walker P. Physiological responses of plants to heavy metals and the quantification of tolerance and toxicity. Chemical Speciation \& Bioavailability. 1989;1(1):7-17. 
38. Liu D, Jiang W, Li M. Effects of trivalent and hexavalent chromium on root growth and cell division of Allium cepa. Hereditas. 1992;117(1):23-9.

39. Zeid IM. Responses of Phaseolus Vulgaris chromium and cobalt treatments. Biol Plant. 2001:44:111-5.

40. Wyszkowski M, Radziemska M. Effects of chromium (III and VI) on spring barley and maize biomass yield and content of nitrogenous compounds. J Toxicol Environ Health. 2010;73(17-18):1274-82.

41. Asati A, Pichhode M, Nikhil K. Effect of heavy metals on plants: an overview. International Journal of Application or Innovation in Engineering \& Management. 2016;5(3):56-66.

42. Boonyapookana B, Upatham ES, Kruatrachue M, Pokethitiyook P Singhakaew S. Phytoaccumulation and phytotoxicity of cadmium and chromium in duckweed Wolffiaglobosa. Int J Phytoremed. 2002;4(2):87-100.

43. Okem A, Stirk WA, Street RA, Southway C, Finnie JF, Van Staden J. Effects of $\mathrm{cd}$ and Al stress on secondary metabolites, antioxidant and antibacterial activity of Hypoxis hemerocallidea Fisch. \& C.a. Mey. Plant Physiol Biochem. 2015;97:147-55

44. Rai V, Tandon PK, Khatoon S. Effect of chromium on antioxidant potential of Catharanthus roseus varieties and production of their anticancer alkaloids: vincristine and vinblastine. Biomed Res Int. 2014. https://doi.org/10.1155/ 2014/934182.

45. Ibrahim MH, Kong YC, Zain NAM. Effect of cadmium and copper exposure on growth, secondary metabolites and antioxidant activity in the medicinal plant Sambung Nyawa (Gynura procumbens (Lour.) Merr). Molecules. 2017. https://doi.org/10.3390/molecules22101623.

46. Kováčik J, Babula P, Klejdus B, Hedbavny J. Chromium uptake and consequences for metabolism and oxidative stress in chamomile plants. J Agric Food Chem. 2013;61(33):7864-73.

47. Malmir HA. The relations between phenylalanine-ammonia lyase, glutathione-s-transferase activities and the concentrations of total tannins, phytochelatins, glutathione, and peroxidation in two cultivars of Sorghum (Sorghum bicolor (L.) Moench) exposed to aluminum. Agric Res. 2012;1(3): 240-50.

48. Baslam M, Garmendia I, Goicoeche N. Enhanced accumulation of vitamins, nutraceuticals and minerals in lettuces associated with arbuscular mycorrhizal fungi (AMF): a question of interest for both vegetables and humans. Agriculture. 2013;3:188-209.

49. Yadav SK. Heavy metals toxicity in plants: an overview on the role of glutathione and phytochelatins in heavy metal stress tolerance of plants. S Afr J Bot. 2010;76:167-79.

50. Emamverdian A, Ding Y, Mokhberdoran F, Xie Y. Heavy metal stress and some mechanisms of plant defense response. Sci World J. 2015. https://doi. org/10.1155/2015/756120.

51. Sullivan ML. Beyond brown: polyphenol oxidases as enzymes of plant specialized metabolism. Front Plant Sci. 2014;5:783.

52. Rai V, Mehrotra S. Chromium-induced changes in ultramorphology and secondary metabolites of Phyllanthus amarus Schum \& Thonn. - an hepatoprotective plant. Environ Monit Assess. 2008:147:307-15.

53. Zhang XH, Liu J, Huang HT, Chen J, Zhu YN, Wang DQ. Chromium accumulation by the hyperaccumulator plant Leersia hexandra Swartz. Chemosphere. 2007;67(6):1138-43.

Ready to submit your research? Choose BMC and benefit from:

- fast, convenient online submission

- thorough peer review by experienced researchers in your field

- rapid publication on acceptance

- support for research data, including large and complex data types

- gold Open Access which fosters wider collaboration and increased citations

- maximum visibility for your research: over $100 \mathrm{M}$ website views per year

At BMC, research is always in progress.

Learn more biomedcentral.com/submissions 